\title{
The Culture of the Jesuit Teacher 1548-1773
}

\author{
PaulF. Grendler \\ University of Toronto, emeritus \\ paulgrendler@gmail.com
}

\begin{abstract}
The culture of the Jesuit teacher consisted of his daily pedagogical attitudes, habits, and practices. In 156o, General Laínez decreed that the schools were the most important ministry and that all Jesuit scholastics and priests must teach. All taught grammar and humanities classes in the lower school for three to five years, and some Jesuits spent most of their careers teaching in the upper school. Learning to manage a classroom of fifty to one hundred boys with the aid of student helpers called decurions was part of teacher culture. Jesuit teacher culture strongly emphasized competition. It rewarded good students and punished weak students. A major purpose of Jesuit teacher culture was to educate boys to be good future leaders of the state and the church. Jesuit teacher culture gave preference to well-born students. It also urged teachers to help lowborn and academically weak students.
\end{abstract}

\section{Keywords}

Diego Laínez - schools - culture - competition - decurions - Jesuit civic humanism elite students - poor students - Tommaso Termanini

A few years ago, as I was doing research in the Archivum Romanum Societatis Iesu, I encountered many heartfelt letters from Italian Jesuits of the late sixteenth and early seventeenth centuries, begging the general to send them as missionaries to Asia. They wanted to be missionaries even though fifty per cent of them would die during the six-month-long sea voyage to Asia. They knew that they might suffer excruciatingly slow and painful martyrdoms. They knew that in their agony they might renounce their faith and doom their souls to eternal damnation. Nevertheless, they pleaded to be missionaries. I mentioned this to a Jesuit friend. "Well," he said, "after spending years teaching Latin grammar to boys, martyrdom might not look so bad."

(C) GRENDLER, 2016 | DOI: 10.1163/22141332-00301002

This is an open access article distributed under the terms of the Creative Commons Attribution-

Noncommercial 4.o Unported (CC-BY-NC 4.o) License. http://creativecommons.org/licenses/by-nc/4,9623 12:20:26PM 
Yet practically every Jesuit priest in the "Old Society" (pre-suppression) accepted the martyrdom of teaching the ablative absolute, correcting thousands of Latin exercises, analyzing Cicero's periods, and managing classrooms of fifty to one hundred students. They did this five hours a day, five to five-andone-half days a week, and ten to eleven months of the year. It must have seemed a tedious way to help souls. But they did it. This article will try to explain the culture of those Jesuit teachers. ${ }^{1}$

Culture can be defined in a variety of ways. The definition followed here is the attitudes, habits, and practices that lead a person to act in identifiable and consistent ways. ${ }^{2}$ The culture of the Jesuit teacher consisted of the attitudes, habits, and practices that led him to teach in certain ways. Much of that culture came from his environment, which was the pedagogical organization, practices, attitudes, and presuppositions of his order-in other words, the Society's teaching culture. Of course, Jesuit teachers firmly believed that a good Christian education would produce upright Christian men who would live righteous lives and achieve union with God in the next life. But Jesuit teaching culture mostly came from their daily teaching experiences, what they did in the classroom. The evidence considered here comes from Italy in the centuries before 1773 , but it is likely that the teaching culture of Jesuits in other parts of Europe in those centuries was very similar. ${ }^{3}$

\section{The Schools Are the Most Important Ministry}

The starting point of Jesuit teacher culture is that all Jesuits taught. When a youth or young man entered the Society, he knew that he would be a teacher. Whatever else he might do as a Jesuit, he knew that he would teach. This was the result of some pragmatic decisions.

1 This is the slightly enlarged and documented text of the lecture delivered at the International Symposium on Jesuit Studies at Boston College on June 11, 2015. The text tries to maintain the style of the lecture. I am grateful to Robert Maryks for the invitation, Maureen Nowak of the Institute for Advanced Jesuit Studies for her assistance, and everyone who participated in the symposium.

2 This is my definition. Although not the same, it is somewhat influenced by the works of George L. Mosse writing about other centuries. See his The Culture of Western Europe. The Nineteenth and Twentieth Centuries. An Introduction (Chicago: Rand McNally, 1961), 1-9.

3 Mission teaching culture outside of Europe will not be discussed, because I have not studied mission schools. Teaching students unfamiliar with European Christian civilization may have necessitated changes in approach and, hence, culture. Nor will catechetical teaching be discussed. Although very important to the Jesuits, it was a different form of instruction. 
Ignatius Loyola determined the future direction of the Society by giving precedence to the founding of colleges with schools over professed houses. And after the opening of the first European school at Messina-Gandía hardly counts-in 1548, Ignatius hastened to found many more. Ignatius was an inspired and inspiring leader who saw an opportunity to help souls through education and leaped to embrace it. But there was no overall plan. When a prince or a city wanted a school, or when Ignatius saw the opportunity to found a school in a strategic center, or saw establishing a school as a means of making the faith stronger or winning back Protestants, he seized the opportunity. He then sent any Jesuit who was available to open the college and to teach, whether the Jesuit was well-educated and prepared to do so or not. Some of these men had very little preparation as Jesuits or as educators. Fortunately, a significant number of the early Jesuits were very talented men who coped with new situations brilliantly. Moreover, when an opportunity to found a new college and school arose, Ignatius tended to send his best people, which sometimes meant that brilliant and energetic young Jesuits such as Peter Canisius (1521-1597) moved around a great deal. He came to teach in a new college, then after a year, having made a brilliant start and attracted many students, Ignatius sent him somewhere else to repeat the process. Loyola was a brilliant opportunist. He saw an opportunity to make the Society relevant to his times. He had a goal but not a long-term plan to bring it to fruition. For example, while Ignatius discussed the organization of Jesuit schools and universities, curriculum, and student behavior in the Constitutions, he did not discuss the Jesuits as teachers. ${ }^{4}$ When Ignatius died on July 31,1556 , his educational legacies to the Society were forty-six schools and a desperate teacher shortage. ${ }^{5}$

4 The Constitutions of the Society of Jesus and Their Complementary Norms (St. Louis: The Institute of Jesuit Sources, 1996).

5 Both Ladislaus Lukács, "De origine collegiorum externorum deque controversiis circa eorum paupertatem obortis 1539-1608," Archivum historicum Societatis Iesu 29 (1960), 189-245, in particular 190 n. 5 and 242-43; and Alan P. Farrell, The Jesuit Code of Liberal Education. Development and Scope of the Ratio Studiorum (Milwaukee: Bruce Publishing Company, 1938), 431-35, give the number of European Jesuit school as thirty-three in 1556, and this is the number given in Paul F. Grendler, "Laínez and the Schools of Europe," in Diego Laínez (1512-1565) and his Generalate. Jesuit with Jewish Roots, Close Confident of Ignatius of Loyola, Preeminent Theologian of the Council of Trent, ed. Paul Oberholzer S.J. (Rome: Institutum Historicum Societatis Iesu, 2015), 639-68, here 647. However, combining the number of Jesuit establishments listed in Yearby-Year with the Early Jesuits (1537-1556). Selections from the "Chronicon" of Juan de Polanco, S.J., trans. John Patrick Donnelly (St. Louis: The Institute of Jesuit Sources, 2004), xxi, which is based on Polanco's Chronicon, with the knowledge that many Jesuit residences became colleges with schools by 1556 , leads to a revised number of forty-six European schools. 
His successor, Diego Laínez (1512-1565, vicar general from $155^{6}$ and superior general from 1558), and his lieutenants, Juan Alfonso de Polanco (1517-1576) and Jerónimo Nadal (1507-1580), continued the policy of opening as many new schools as possible, as quickly as possible. Laínez in particular placed a higher priority on the schools in central Europe than those in Italy and Spain. ${ }^{6}$ The reason was to solidify Catholics in their faith and to win back Protestant souls. When Laínez died on January 19, 1565, there were ninety-one Jesuit schools across Europe. ${ }^{7}$

But the teacher shortage really hit home during the generalate of Laínez. He and his lieutenants attempted several expedients, some of them foolish. For example, on October 1, 1557, Laínez sent a letter to the rectors of all the Italian colleges telling them to reduce the number of classes they offered and to let class sizes grow. The result was predictable: when the number of lower classes shrank, but class sizes rose in the remaining classes, fewer students did well enough to qualify academically for the next class. ${ }^{8}$

Laínez finally hit on the solution: all Jesuits would teach. On August 10, 156o, Polanco, writing for Laínez, sent a letter to all the superiors of the Society. He began by praising teaching because it served the common good. He continued, "Generally speaking, there are two ways of helping our neighbors: one is in the colleges by the education of youth in letters, learning, and Christian life. The other is to help all universally through preaching, [hearing] confessions, and all the other means in accord with our customary way of proceedings." ${ }^{\prime 9}$ This

6 Grendler, "Laínez," $65^{2}$.

7 For the schools added during the generalate of Laínez, see Mario Scaduto, L'epoca di Giacomo Laínez 1556-1565. L'azione (Rome: La Civiltà Cattolica, 1974), 793-99; and Grendler, "Lainez," 647-51.

8 Letter of Laínez to the rectors of Italian colleges, Rome, October 1, 1557, in Monumenta paedagogica Societatis Iesu, ed. Ladislaus Lukács, 7 vols. (Rome: Monumenta Historica Societatis Iesu, 1965-92), 3:262-63 [hereafter Mon. paed.]; and letter of Guidone Roillet, Ferrara, October 22, 1557, in Mon. paed. 3:263n2.

9 "Et così essendovi generalmente parlando due maniere di aiutar le prossimi, una nelli collegii con la institutione della gioventù nelle lettere, dottrina et vita xpiana, l'altra con aiutar universalmente tutti con le prediche et confessioni, et altri mezzi conformi al nostro solito modo di procedere." Letter to the superiors of the Society, Rome, August 10, 1560, in Epistolae et acta Patris Jacobi Lainii secundi praepositi generalis Societatis Jesu ex autographis vel originalibus exemplis potissimum deprompta a patribus ejusdem Societatis edita, vol. 5, 1560-1561 (Madrid: G. López del Horno, 1915), 165-67, here 165. It is also printed in Mon. paed. 3:304-6, quote on 305. Lukás stated that the letter signaled a policy change, but did not recognize its importance (Mon. paed. 2:37*). John W. O'Malley, The First Jesuits (Cambridge, MA: Harvard University Press, 1993), 200, is the first scholar to recognize that it made the schools the most important ministry of the Society. 
was extraordinary and unprecedented: Laínez was telling the members of the Society that the ministry of the schools was as important as all the other ministries combined. Laínez then explained what this meant: every Jesuit must ordinarily "bear part of the burden of the schools." ${ }^{\text {"0 }}$ He meant that every Jesuit would teach. Most Jesuits would teach in the lower school after completing humanistic studies and before beginning philosophical studies. Some would teach after completing philosophical studies, and still others after completing theological studies. Superiors would help place a Jesuit in the occupation for which he was most suitable, taking into account the common need. They were also to present annual assessments of the Jesuits in their charge. The letter concluded with yet more praise of the schools.

One must understand what Laínez and Polanco meant by "all Jesuits." They meant that all Jesuits studying to be priests, or already ordained priests, would teach. They did not mean that Jesuit brothers - their title was "temporal coadjutor" - would teach. Probably very few of these men were Latin-literate, and some brothers were illiterate. And so far as can be determined, the Society provided little or no academic schooling to what they brought with them.

Ignatius's actions had made the decision by his actions that the schools were the Society's most important ministry. But he did not create a policy that would make this happen. Laínez did. It was he who structured the career paths of Jesuits in a way that supported the schools. Although he allowed for exceptions, Laínez made it clear that all Jesuits intended for ordination would teach in the course of their careers. Most would teach in the lower school, which required the greatest number of teachers, because the Jesuits taught two to three times as many courses in grammar, humanities, and rhetoric, as they did in logic, natural philosophy, metaphysics, mathematics, and Scholastic theology.

There were two circumstances surrounding Laínez's decree that have not been noticed. First, he made the decision, possibly with the agreement of Polanco and whichever other Jesuits in Rome whom he may have consulted. In any event, it was not widely discussed, at least not on paper. Laínez did not write to other important Jesuits for advice on this matter. And while there are nearly seven hundred pages of documents discussing and debating the organization of schools, curriculum, pedagogical practice, textbooks, and so on, in the 1540 s, 1550 s, and in 1560 s, in the magnificent and indispensable Monumenta paedagogica edited by Ladislaus Lukács, there is no mention prior to 1560 that

$10 \quad$ "[...] che tutti ordinariamente doveranno portar parte del peso delle schuole." Letter to the superiors of the Society, Rome, August 10, 1560. Epistolae et acta Patris Jacobi Lainii, 5:166. 
all Jesuits except brothers would teach. ${ }^{11}$ Moreover, neither the first general congregation (1558) nor the second (1565) discussed Laínez's decree. Indeed, the first two congregations devoted very little attention to the schools. And when they did turn to the schools, they addressed administrative matters, such as the number of teachers that a college of a certain size should support. ${ }^{12}$ This extraordinarily important decision seems to have come out of nowhere.

The second point is that no Jesuit objected. It was accepted and implemented without objection or fanfare. ${ }^{13}$ This was unusual for the Jesuits. Anyone who has read the documents knows that the sixteenth-century Jesuits were not docile, cadaver-like, supinely-obedient soldiers of Loyola sometimes portrayed in histories of the Jesuits. There were controversies which elicited full discussions and some open rebellions. ${ }^{14}$ But so far as can be determined, they did not object to the decree of Laínez that the schools were the most important ministry and that all Jesuits would teach. This meant that the first generation of Jesuits had also come to the conclusion that the Society would be a teaching order. And that all would share in the burden of the schools. A teaching culture already existed in the Society at this time.

Laínez's decision did not solve the teacher shortage immediately. He and Polanco still scrambled to fill pedagogical holes, especially in central Europe. One unfortunate Jesuit had to teach in Rome, Forlì, Bologna, Milan, and Rome again between September 1562 and January 1565 , five postings in twenty-eight months. ${ }^{15}$ Rectors of Jesuit colleges bitterly complained to Rome about the movement of teachers. One of them pointed out that one mediocre teacher who stayed was better than a brilliant teacher who left after a few months. ${ }^{16}$ No

11 See Mon. paed., vols. 1-3. Of course, the Mon. paed. does not include everything pertaining to the schools in those years. But there is nothing like this in the letters of Ignatius, Laínez, and Nadal, or any other documents that I have seen.

12 John W. Padberg, Martin D. O'Keefe, and John L. McCarthy, eds., For Matters of Greater Moment. The First Thirty Jesuit General Congregations. A Brief History and a Translation of the Decrees (St. Louis: Institute of Jesuit Sources, 1994), 65-134. For the 1565 recommendations on the number of teachers and Jesuits in a college, see ibid., 113-14, 133-34.

13 See Mon. paed., vols. 2-3 with documents from 1557 through 1572 . It is very unlikely that Lukács would have omitted anything on this topic.

14 The most lacerating and disgraceful was over Jesuits of converso ancestry. See Robert A. Maryks, The Jesuit Order as a Synagogue of Jews. Jesuits of Jewish Ancestry and Purity-ofBlood Laws in the Early Society of Jesus (Leiden: Brill, 2010).

15 Scaduto, L'epoca di Giacomo Laínez, 450.

16 Letter of Filippo Trivisano, Forlì, April 15, 1571, in Archivum Romanum Societatis Iesu [hereafter ARSI], Ital. 141, f. $144^{\mathrm{r}-\mathrm{v}}$. 
school principal in any century would deny this truth. But over time Laínez's decree solved the teacher shortage. It created a supply of teachers. It enabled generals and provincial superiors to plan ahead. They knew that they would have a definite number of Jesuits available to teach in a few years. Laínez's decision made possible the enormous educational expansion that began in the late sixteenth century and reached fruition in the seventeenth. The Jesuits founded many new schools, and added classes to existing schools.

The Jesuits implemented Laínez's directive in the sixteenth, seventeenth, and eighteenth centuries. In the late sixteenth century, some young Jesuits did teach grammar, humanities, and/or rhetoric in the lower school after completing their own humanistic studies. But that changed in the seventeenth and eighteenth centuries. Jesuits did not teach until after they had completed their philosophical studies.

In the seventeenth and eighteenth centuries, the career of a typical Italian Jesuit went as follows. ${ }^{17}$ The youth or young man typically entered the Society at the age of sixteen, seventeen, or eighteen - sometimes older, very occasionally younger. He then spent two years as a novice. After the novitiate, if the young Jesuit was not well-prepared in Latin and Greek, he spent a year or two studying the humanities and/or rhetoric, based on the classics, before going on to philosophical studies. If he was well-prepared in Latin and Greek, he immediately began three years of philosophical studies. That consisted of one year of logic, a second year of natural philosophy, usually called physica because Aristotle's Physics was the major text, and a third year of metaphysics, all based on the appropriate texts of Aristotle. He might also study mathematics if he had the aptitude and the school offered the course. But mathematics was an optional course that did not receive nearly the time or attention of the philosophical trio.

After philosophical studies, the young Jesuit, now aged twenty-three to twenty-five, spent the next three to five years teaching in the lower school. He did not necessarily teach the same course each year, or teach in the same school all of the time. The young Jesuit might teach lower grammar one year, upper grammar the second year, humanities in the third, and rhetoric in the fourth. He might move from one town to another, almost always in his home province. Practically all Jesuits intended to become priests spent three to five years teaching in the

17 The following comments are based on many biographies in Diccionario histórico de la Compañía de Jesús. Biográfico-temático, ed. Charles E. O’Neill and Joaquín M. Domínguez, 4 vols. (Rome-Madrid:Institutum Historicum Societatis Iesu-Universidad Pontificia Comillas, 2001) [hereafter $D H C J$ ] and numerous annual, triennial, and quadrennial catalogues in ARSI that summarize the reports from rectors of colleges and provincial superiors. 
lower school. After the three to five years of lower school teaching, the young Jesuit began four years of theological studies, which took place in the major Jesuit school of his province. A Jesuit was ordained after the third year of theological studies, sometimes in the fourth year. He was then in his early thirties.

In practice, all Jesuits taught in the lower school when they were scholastics. For some Jesuits, this was all the teaching that they did. All Jesuits did not teach in the upper school, because fewer teachers were needed, and because the Society reserved upper school teaching to its better scholars. And only ordained Jesuits taught philosophy or theology. After completing theological studies and ordination, a small number of Jesuits became teachers of philosophy. A Jesuit philosophy teacher taught a three-year rotation of courses. He taught logic the first year, natural philosophy the second, and metaphysics the third, almost always in the same school. He then repeated the cycle. Some Jesuits spent much of their lives teaching the philosophical trio. Others taught the philosophical trio for a few years, then taught theology. After that a Jesuit alternated. He taught philosophy for five or six years, then theology for five or six years, then went back to philosophy. A small handful of Jesuits, considered the leading scholars of the Society, taught theology for the rest of their lives.

But a Jesuit did not normally spend his entire career teaching. Even Jesuits who taught in the lower school usually had other duties as well, such as prefect of a Marian congregation. And those Jesuits who became career teachers did not teach every year. This was the other part of Laínez's decree, that Jesuits would serve in multiple ministries. Every few years a Jesuit was assigned another duty for a year or more. He might become the prefect of studies, the Jesuit who oversaw the school but did not teach. He might be appointed rector of a college. Rectorships usually lasted two or three years, after which the Jesuit might return to teaching, be appointed rector of another college, or be given another duty. The needs of the Society always came first. In this way the Society fulfilled the promise of the second part of Lainez's decree, that all Jesuits would serve in other ministries as well. Thus, the Society also succeeded in building a considerable amount of ministerial variety into the lives of individual Jesuits. In the sixteenth century, members of the Society also moved from place to place within the assistancy. In the seventeenth and eighteenth centuries, when the Society had many more members, there was less movement from position to position and place to place, and the movement was almost always within the province. In summary, all Jesuits intended for the priesthood taught in the lower school. After ordination, some Jesuits taught philosophy, and a few taught theology for most, but not all, of the rest of their lives. A tiny number of Jesuits learned mathematics and spent most of their careers teaching only mathematics, because it was such a specialized subject. 
Thus, part one of the culture of the Jesuit teacher was that he knew that he would teach and he did teach. He did not enter the Society knowing he would a missionary, or a catechist, or a chaplain to the sick, or rector of a college, or confessor to a prince, or the author of books. He might do all of these; he might do none of these. But he knew that he would be a teacher. Teaching was fundamental to his identity as a Jesuit.

\section{Leader and Manager of the Classroom}

The next component of the culture of a Jesuit teacher is that he was the leader and manager of the classroom. The words "leader" and "manager" are used deliberately.

To explain this, some enrollment statistics are needed. In the autumn of 1660, the Jesuit school at Brescia in northern Italy offered six classes taught by Jesuits in their regular curriculum. They had the following enrollments (starting from the lowest class): lower grammar eighty-three students, middle grammar sixty-eight students, upper grammar fifty-nine students, humanities ninety students, rhetoric fifty students, philosophy (whether this was a course in logic, or natural philosophy, or a combination of the two, was not indicated) eighty-seven students. ${ }^{18}$ The total was 437 students in six classes, an average of seventy-three students per class. The Brescia school has been chosen because it was an average Italian Jesuit school at that time, in terms of the number of classes, the number of teachers, and class size. Larger Jesuit schools in Italian cities had more classes and higher class enrollments. Grammar and humanities classes with more than one hundred students were common. ${ }^{19}$ Jesuit

18 ARSI, Ven 97 I, f. 139v', no date (but September 1660). The cases of conscience lectureship, which had an enrollment of fifty, is excluded because it was not part of the graduated regular curriculum. The cases lectureship was a service course in practical moral theology intended for the confessors of the town. Cases lectures might meet only three times a week for an hour or so, instead of five or six days a week and five-plus hours a day as the grammar, humanities, and rhetoric courses did, or two to two-and-one-half hours daily, as did the philosophy courses. Also excluded is a preparatory class of sixty students. Taught by a secular priest hired by the Jesuits, this class taught reading and writing and the first elements of Latin grammar. A boy had to be able to read and write and possess some knowledge of Latin grammar before he could be accepted into the lowest Latin grammar class of the Jesuit school. The preparatory class or a non-Jesuit school provided it.

19 For example, in January 1661 the Jesuit school at Milan had five grammar classes enrolling 646 students, two humanities classes with 210 students, and two rhetoric classes with 124 students. The total was 980 students in 9 classes, an average of 109 students per class. Each 
schools in smaller towns than Brescia had smaller class enrollments. Class sizes were very high in comparison to twenty-first-century North American public school standards.

How did a single teacher manage to teach Latin and some Greek to a class of sixty to ninety boys and youths, aged ten to eighteen? The first and most important answer is that teachers, students, and parents were dedicated to teaching and learning. The second answer is that the Jesuits developed a combination of organizational principles and student assistance that enabled the teacher to manage a very large class.

One must look inside a class. Fortunately, a young man named Pietro Antonio Adami (1661-1722), a native of Bologna, enables us to do this. He was a student in the lower school of the Jesuit school in Bologna in the $1670 \mathrm{H}$. He entered the lower grammar class on November 12, 1675, at the age of fourteen, somewhat older than the norm. He spent one academic year in the lower grammar class, the next year in the upper grammar class, a third year in the humanities class, and two years in the rhetoric class, for a total of five years. He emerged from the rhetoric class on August 20, 1680, when he was nineteen. He then wrote a detailed description of his five years in the Bologna lower school. Since the prefect of studies read and approved Adami's account, it can be trusted to be accurate. After leaving the Jesuit school, Adami became an Oratorian priest (Congregation of the Oratory of Saint Philip Neri) and eventually acquired a doctorate in theology. ${ }^{20}$

Classrooms were large. ${ }^{21}$ The teacher sat in a big chair with a table in a commanding position. There were also two or three other chairs, sometimes with small tables, for the emperor and princes (see below). These were placed between the teacher and the rest of the students. The rest of the students sat in assigned places on rows of benches. The ceiling (in this instance) was decorated with a fresco depicting the victory of Rome over Carthage and a motto. There were portraits of ancient poets and orators. Paintings of canonized and beatified Jesuits hung on the walls, typically St. Ignatius of Loyola, Luigi

class was taught by a single Jesuit. ARsI, Med 73, ff. 168-69v; and Simona Negruzzo, Collegij a forma di seminario. Il sistema di formazione teologica nello Stato di Milano in età spagnola (Brescia: Editrice La Scuola, 2001), 129.

20 The text is edited and printed in Natale Fabrini, Un documento bolognese inedito su le scuole dei gesuiti (Rome: Stella Matutina, 1946), who also provides a brief introduction, notes, and a biography of Adami at p. 5. Gian Paolo Brizzi, "La scolarité de Pietro Antonio Adami chez les jésuites de Bologna à la fin du XVII ${ }^{\mathrm{e}}$ siècle," in Histoire de l'éducation 124 (2009): 51-71, provides an excellent analysis.

21 Since Adami described several classrooms and class practices in greater or lesser detail, what follows is a composite picture. 
(Aloysius) Gonzaga (1568-1591), and Stanisław Kostka (1550-1568). The latter two were honored as examples for and patrons of youth in Jesuit schools across Europe. Classrooms normally had one or more windows for light and circulation. There was no stove. However, in the winter braziers with hot coals were brought in to provide limited warmth in classrooms of younger boys. Classrooms were hot in the summer. ${ }^{22}$

The teacher organized his class into decuries, led by decurions. A decury was a group of ten students of about the same level, led by the best student, who assisted the teacher by overseeing the studies of the other nine. In the ancient Roman army, a decury was a group of ten soldiers led by one of them, the decurion. Medieval schoolmasters adapted the term to describe students who assisted the teacher, and Renaissance pedagogues, such as members of the Brethren of the Common Life, followed suit. ${ }^{23}$ The Jesuits began to use student decurions soon after they became schoolmasters. In 1558 , Jesuit teachers in Sicily recommended that when the class was large, the teacher should create decurions who, under his direction, could oversee the other students part of the time. ${ }^{24}$ Decuries then became a staple of Jesuit classes throughout Europe.

Decuries and decurions fitted neatly into the daily routine of lower school classes. It consisted of a tightly-integrated program including the teacher's exposition of the material to be learned that day, memorization, recitation, composition exercises, correcting compositions, review, and homework to be submitted every day except Saturday. ${ }^{25}$ At the beginning of the school day, decurions collected student homework and passed it on to the teacher for correction. They kept a record of those students who did not do the written work. Then, in the first hour of a grammar class, a decurion heard the recitations of memorized material, such as rules of grammar or lines from Cicero, from the other nine members of his decury. Decurions had the honor of reciting before the chief decurion of the class, or the teacher. The teacher then corrected each student's written work individually, explaining the mistakes in a low voice. In the meantime, the other students did exercises. ${ }^{26}$

\footnotetext{
22 Fabrini, Un documento bolognese, 18, 30-31, 50, 52-53, 61.

23 Gabriel Codina Mir, Aux sources de la pédagogie des jésuites. Le "modus parisiensis" (Rome: Institutum Historicum Societatis Iesu, 1968), 13-38, 168-72, and passim.

24 "Ubi multitudo magna est, constitui oportet decuriones, qui aliorum curam aliquam habeant sub praeceptore et ab ipso praefinitam." Mon. paed. 2:35, part of an anonymous "Regulae praeceptorum (Forma sicula), Anno 1558."

25 The Ratio studiorum. The Official Plan for Jesuit Education, ed. and trans. Claude Pavur (St. Louis: The Institute of Jesuit Sources, 2005), 143 (paragraph 344).

26 Ratio studiorum, 106, 126, 142-43, 150, 156, 167, 174, 180, 185 (paragraphs 230, 287, 343, 36o, $376,396,406,416,426)$.
} 
To make all of this work in a class of seventy or more students, the Jesuit teacher had to be well organized, command respect, and possess good judgment-not least in his choice of decurions. Although he was the teacher, a commanding figure, he was also the leader of a team. Part of the culture of the Jesuit teacher was that he was the manager and leader of a large classroom.

\section{The Culture of Competition}

The use of decurions as teacher helpers dovetailed with an essential cultural characteristic of Jesuit education: competition. The Ratio studiorum uses the term "rivalry" (aemulatio). Schoolroom competition did not originate with the Jesuits, for Erasmus (1466-1536) and other Renaissance pedagogical writers had endorsed rivalry. ${ }^{27}$ But it became very important in Jesuit schools. For example, if the large number of students did not permit the teacher time to correct all the written work himself, some of it could be distributed to "rivals" (aemuli) to correct. ${ }^{28}$ The teacher authorized rivals to correct each others' compositions, review exercises and oral presentations, and quiz each other ${ }^{29}$ If a student missed a mistake in a rival's paper, the student who missed the mistake was penalized. The Jesuits endorsed rivalry because they believed that competition led to greater academic achievement. It also relieved teachers of some of the enormous burden of correcting the mountain of written work that students produced, and of hearing recitations from every student in the class.

Competition was essential to Jesuit pedagogy, especially in the lower school. In the Bologna lower school of the 1670 s, practically every student exercise or recitation was graded with positive and negative points (punti), with the grading done by the teacher or other students. Even student responses in the catechism classes were given positive and negative grades. ${ }^{30}$ At Bologna, ordinary

27 Codina Mir, Aux sources le la pédagogie, 134-36, 223.

28 "Every day everyone's written work ought to be corrected by the teacher, since that is the source of the greatest and most substantial benefit. Nevertheless, if the large number does not allow it, he should correct as many as he can [...]. For this reason [...] he should distribute some written work to be corrected by the rivals (aemuli)" [facilitating this by having each one write on the back of the assignment not only his own name but the name of his rival as well]." Ratio studiorum, 144 (paragraph 347). Aemuli means either friendly or hostile rivals. Student rivals in Jesuit schools were expected to be friendly rivals.

29 Ratio studiorum, 145, 148, 162, 171, 178, 183-184, 189 (paragraphs 349, 355, 386, 401, 414, 424, 433). Other references to rivalry are found at pages 143-44, 176, 181-82, 187 (paragraphs $346,408,418$, and 428 ).

3o Fabrini, Un documento bolognese, 48. 
students recited to decurions, decurions to princes, the princes to the emperor, and the emperor to the teacher. The grades included optime, bene, male, pessime, and nescit (ignorant). Students who misbehaved, were unpunctual, or showed up in class without paper, pen, and ink also received negative points. Students called "censors" kept track of the points on large sheets of paper. At the end of the week or month, the points were added. The student with the highest number of points was named emperor, the next highest became princes. The competition also included groups of students; indeed, the students of the grammar and humanities classes were divided into two republics, Rome and Carthage, who also contended with each other. The scores determined the seating arrangements. All the students had designated places to sit; the emperor in the highest chair, the princes in other chairs, the rest of the students on benches. At the end of the competition period the students moved up or down, or retained their chairs and benches. ${ }^{31}$ This was the way that the Jesuit school at Bologna put into practice the emphasis on rivalry mandated by the Ratio studiorum.

Although such intense academic competition is probably not seen today in schoolrooms in North America, some level of academic competition still exists. ${ }^{32}$ Moreover, schoolboys and schoolgirls today compete vigorously for places on sports teams and sometimes in music. Student musicians audition for places in the band or orchestra, and the best become first chairs. In addition, the competition may continue through the year. For example, the second trumpet player might challenge the first trumpet for his or her position. The conductor hears each play passages from the music in the upcoming concert, then awards the first trumpet chair to the one who plays better. And maybe the loser practices harder and wins back his or her position at the next challenge day. The goal is better musical performance.

In Jesuit schools, there were many rewards for the best students, including public recognition, such as performance before one's peers, teachers, parents, and guests. At the Bologna Jesuit school, a wooden escutcheon with the name

\footnotetext{
$31 \quad$ Ibid., 35, 37-39.

32 Nevertheless, I suspect that academic competition, whether encouraged or not, is found in almost all classrooms. A personal example. I attended high school in a small town in Iowa in the early 1950 s in which there was no social or other recognition for academic achievement beyond report cards. Nevertheless, the two best students in my graduating class were myself and a girl. We were de facto decurions and competitors, and everyone in the class knew this. How did we and they know this? When the other students in advanced mathematics classes encountered difficulties, the boys came to me for help, and the girls went to my rival. When she could not solve the problem, she came to me. She hated having to do this, but she did it.
} 
of the student, his patria, title, motto, impresa, and coat of arms (if he had one) might be created. It was then hung on the wall of the classroom. This was imitation of university practice. The walls of the courtyard of the Archiginnasio building, at that time the home of the University of Bologna, are lined with such student escutcheons. In the Jesuit school, the best compositions in the grammar classes were posted outside the classroom, and sometimes sent to a higher class to be applauded..$^{33}$ Jesuit classrooms were wonderful places for academically gifted students. They did well and received public recognition from teachers, peers, and others. This stimulated them to study harder and to achieve yet more.

On the other hand, the students who performed poorly and/or misbehaved received demerits and suffered humiliation and punishment. The worst compositions were sometimes posted so they could be ridiculed. The student with the lowest score as a result of poor academic performance and misbehavior was declared the asino of the class. A picture of an ass was attached to his neck, and a mitre shaped like an ass placed on his head. He had to wear the picture of the ass around his neck until he improved, and he might be sent around to other classes to be ridiculed. ${ }^{34}$

Jesuit pedagogical culture gave little or no recognition to students of average abilities. The Ratio studiorum advised only the spur of competition and peer pressure to encourage students of ordinary intellectual ability to do well. The Jesuits made some allowances for weaker students by permitting students to repeat classes and by allowing some weak students to advance because of their age or family pleading. Such students were viewed as benchwarmers at the Bologna school..$^{35}$ The Ratio studiorum advised that students who, after an extensive period in the school, were judged incapable of learning enough to advance to the next class should be dismissed - "after their parents or guardians have very courteously been given notice."36 Diminishing enrollments in the higher classes of the lower school argue that many students dropped out. Jesuit schools and teachers focused on stimulating the ablest students to high achievement and giving a thorough education to everyone else capable of progressing. Academically gifted students who studied hard and achieved excellent results were more important than the rest. This was part of the academic culture of Jesuit teachers.

\footnotetext{
33 Fabrini, Un documento bolognese, 34, 40, 50.

34 Ibid., 34-39.

35 “[... $]$ ma sono poi sempre per scaldabanco." Ibid., 42.

$36 \quad$ Ratio studiorum, 122 (paragraph 275).
} 
An emphasis on competition and high achievement was typical of pedagogical philosophy of those centuries, and Jesuit teachers were men of their times. Moreover, many of them had studied in this culture, because they attended Jesuit schools before they joined the Society. And it is very likely that Jesuit teachers themselves participated in this competitive culture by trying to be the best teachers they could be.

\section{Jesuit Civic Humanism}

On December 1, 1551, Polanco, on commission from Ignatius, wrote to Antonio de Araoz (1515-1573), provincial superior for Spain. The letter offered an explanation and justification for Jesuit education, especially the education of lay students. Polanco stressed that the purpose of Jesuit education was to train the student and to be useful. He gave fifteen reasons why a Jesuit education was useful to three groups: the Jesuits themselves, external students and their parents, and the people of the country or territory in which a Jesuit school was located. ${ }^{37}$

The last group emerged most clearly in the fifteenth benefit of a Jesuit education:

15. From among those who are at present only students, various persons will in time emerge-some for preaching and the care of souls, others for the government of the land and the administration of justice, and others

The key portion of the letter is found in Sancti Ignatii de Loyola Societatis Jesu fundatoris epistolae et instructiones, vol. 4 (Madrid: G. López del Horno, 1906), 7-9, entire letter pp. 5-9, written in Spanish. It is reprinted in Mon. Paed. 1:413-19, with the fifteen benefits at 417-19. For English translations of the entire letter see John Patrick Donnelly, ed. and trans., Jesuit Writings of the Early Modern Period, 1540-1640 (Indianapolis and Cambridge: Hackett Publishing Company, Inc., 2006), 33-37 (trans. George Ganss); and Ignatius of Loyola. Letters and Instructions, ed. Martin E. Palmer, John W. Padberg, and John L. McCarthy (St. Louis: The Institute of Jesuit Sources, 2006), 36o-63 (trans. Palmer and Padberg). For a combination translation and close paraphrase of the fifteen benefits only, see O'Malley, First Jesuits, 212-13; and O'Malley, "Jesuit Schools and the Humanities Yesterday and Today," in Studies in the Spirituality of Jesuits 47, no.1 (2015): 34. Polanco's key words were utilidad and utilidades, both used several times. Ganss and Palmer and Padberg translate these as "advantage" and "advantages" most of the time; O'Malley always uses "benefit" and "benefits." Both advantage and benefit convey the meaning of utilidad well. Utilidad might best be translated as "usefulness." But no English translator wants to write "usefulnesses." 
for other responsibilities. In short, since young people turn into adults, their good formation in life and learning will benefit many others, with the fruit expanding more widely every day. ${ }^{38}$

Thus Polanco made it clear that the Jesuits were training the future leaders of the church, the state, and society. If they were formed well as boys, they would be good leaders as adults, and their actions would benefit many others.

Whether he was aware of it or not, Polanco reiterated the views of fifteenth-century Italian pedagogical humanists, men such as Pier Paolo Vergerio (c.1368-1444), Vittorino Ramboldoni da Feltre (1373 or $1378-$ 1446/1447), and Guarino Guarini of Verona (1374-1460). They believed that Renaissance schoolboys should study the classics of ancient Rome and Greece in order that they might become eloquent, virtuous, and wise leaders of civic society as adults. ${ }^{39}$ The best name for the view that a humanistic education prepared boys to be leaders of society as adults is civic humanism. ${ }^{40}$ Like the fifteenth-century Italian pedagogical humanists, Polanco (and Loyola) believed that a Jesuit education prepared boys for professional positions and leadership roles for the ultimate benefit of all. By adding ecclesiastical society to civil society, Polanco described Jesuit civic humanism.

Future Jesuits extolled the civic and ecclesiastical benefits of a Jesuit education in the humanities, sometimes with little reference to the spiritual benefits. An excellent example came from the pen of Fulvio Cardulo (1529-1591). Born in Narni (north of Rome, in Umbria), Cardulo joined the Society of Jesus in

38 Ignatius of Loyola. Letters and Instructions, 363. For the Spanish, see Sancti Ignatii de Loyola Societatis Jesu fundatoris epistolae et instructiones, 4:9.

39 Paul F. Grendler, Schooling in Renaissance Italy. Literacy and Learning, 1300-1600 (Baltimore and London: The Johns Hopkins University Press, 1989), 125-42. For the Latin texts and English translations of four humanistic pedagogical treatises including that of Vergerio and a description of Guarini's school written by his son, see Humanist Educational Treatises, ed. and trans. Craig Kallendorf (Cambridge, MA: Harvard University Press, 2002).

40 The term "civic humanism" is the invention of Hans Baron in his famous book, The Crisis of the Early Italian Renaissance. Civic Humanism and Republican Liberty in an Age of Classicism and Tyranny. Revised one-volume edition with an epilogue (Princeton, NJ: Princeton University Press, 1966). It was first published in two volumes in 1955. Baron focused on humanism and republican politics in Florence in the early fifteenth century. However, historians studying the Italian Renaissance, including myself, have come to realize that in the later fifteenth century and in the sixteenth, civic humanism meant studying the classics as preparation for leadership roles in civil society, whether republic, princedom, or monarchy. 
1546 and was sent to the University of Padua to study, where he attended the lectures of Lazzaro Bonamico (1477/1478-1552), a Ciceronian humanist who had a large reputation that has not endured, because he published little. Cardulo then went to Rome, where he had a long association with the Collegio Romano, including teaching rhetoric from 1553 to 1575 , and possibly longer. He orated before popes, published two books on Christians martyred by Emperor Diocletian (245-311, r. 284-305), and left manuscript commentaries on Cicero and Virgil. ${ }^{41}$

In 1584, Cardulo addressed a fervent plea to the committee charged with preparing the Ratio studiorum on the importance of a humanistic education for students who would be leaders of society. He began by saying that teaching the humanities was an enterprise undertaken by the Society for the honor of God and for "the universal help of the Christian state" (per aiuto universale della repubblica christiana). But the Jesuits had not been doing a very good job of it recently, in the judgment of princes, prelates, and judicious and learned men who love the Society. Cardulo then offered a strong civic justification for teaching the humanities. The Society did not just teach Latin grammar and language, but had a higher aim, that of molding political men useful for the city. The goal of the Society was to instruct noble youths in such a way that in time they would prove their worth in pulpits, senates, secretariats, and embassies. The prudence and eloquence taught in our schools will serve the Christian state by making our former students into good preachers, senators, secretaries, nuncios, ambassadors, and others who serve the common good, he wrote. ${ }^{42}$

Cardulo then outlined how Jesuit humanities instruction should proceed. It should begin by collecting from good authors diverse materials and

41 Carlos Sommervogel, Bibliothèque de la Compagnie de Jésus, 12 vols. (Brussels-Paris: Schepens-Picard, 1890-1930), 2:744-46; Scaduto, L'epoca di Giacomo Laínez, 295-96; and László Lukács, "Cardulo, Fulvio," DHCJ 1:658-59. There are many references to Cardulo's teaching at the Collegio Romano in Mon. paed. vols. 1-4, from the index.

"Per rimediar a si grave inconveniente et sodisfare al debito nostro, si ha da presuporre che in questa parte intento della Compagnia non deve essere insegnare grammatica et la lingua latina come si voglia, ma devesi pretendere un fine più nobile; cioè formare huomini politici et utili alle città; et tanta ioventù et nobiltà, che i nostri per tutto il mondo tengono sotto la disciplina, instituirla in modo, che col tempo diano di sé assaggio nelli pulpiti, senati, secretarie, ambasciarie. Poiché la prudenza et eloquenza che nelle nostre schole si deve insegnare, servirà alla repubblica christiana, et farà buoni predicatori, senatori, secretarii, nuntii, imbasciatori et altri che servono al ben comune." Cardulo, "Discorso sopra gli studi di humanità (1584)," in Mon. paed. 7:128-29, here 128. 
commonplaces that serve a Christian moral and political end. ${ }^{43}$ Next, the grammar and humanities classes would teach eloquence, history, and poetry. In rhetoric, the most important class, students should practice every sort of verse and prose writing in preparation for careers as preachers, senators, ambassadors, secretaries, and so on. There, they will use the commonplaces, materials, sentences, and discourses that they have learned. ${ }^{44} \mathrm{He}$ concluded by chiding the leadership of the Society for devoting too much attention to theology and not enough to the humanities.

This was a very strong version of Jesuit civic humanism couched in utilitarian and civic terms: Jesuit humanities instruction enabled students to move into important positions in government. Cardulo strongly emphasized the temporal rewards of a Jesuit humanistic education. In a discourse of only eight hundred words, he three times listed the prestigious civil and ecclesiastical positions that students with Jesuit humanistic education were expected to attain. There they would act for the common good, which they could accomplish because they had also received good moral and religious training, although Cardulo practically ignored this part of Jesuit education.

Other Jesuits offered similar statements about how a Jesuit education prepared boys to assume leadership and professional roles in the state and the church. They believed that the future welfare of the state would depend on their students, who will be in positions to help many others and to contribute to the common good. ${ }^{45}$

Italian Jesuits continued to argue that a Jesuit education in the humanities prepared students well to hold important positions in state and society, to earn

43 "Raccoglier da buoni autori materie diverse et luoghi communi, che servano al sopradetto fine christiano morale et politico." Mon. paed. 7:128.

44 “[...] et fare come un corso di rhetorica, esercitandosi in verso et in prosa d'ogni sorte, ordinando tutti gli essercitii litterarii all'officio d'un buon predicatore, senatore, imbasciatore, secretario etc., mettendo in prattica i luoghi communi, materie et sentenze et discorsi raccolti, come s'è detto." Mon. paed. 7:129.

45 See the memorandum of Michele Lauretano of Rome, 1572, extolling the benefits that the pupils at the German College will bring to civil society as future leaders of church and state because of their education. Lauretano (1537-1587) was rector of the German College from 1573 until his death. Mon. paed. 2:995-96, 1000, 1003. Juan Montoya (1527-1592), the rector of the college at Nola (southern Italy) with a school made the same claim in May 1567. Mon. paed. 3:402. So did an anonymous Jesuit writing from Vilnius (Lithuania) in 1570. Mon. paed. 3:575. See also Philip Caliendo, "Latin and Loyola: Means, Ends and Options in Mind," in Jesuit Education and the Classics, ed. Edmund P. Cueva, Shannon N. Byrne, and Frederick Benda (Newcastle upon Tyne: Cambridge Scholars, 2009), 22-40, here $35^{-} 36$, who provides some translations and comments. 
a good living, and to serve the state and the common good, even as civil rulers were pressuring the pope to suppress the Society. Tommaso Termanini (17301797) made this clear. Born in Modena, he entered the Society in 1749, studied at the Collegio Romano from 1751 to 1760 , taught philosophy at Città di Castello and Spoleto until 1763 , after which he conducted missions in Lazio and Tuscany. After the suppression, he may have become an abbot with an unknown religious order in the duchy of Parma. In the 179os, he published a series of biographies of Jesuit missionaries to rural Italy. He also wrote a life of the last Jesuit general before the suppression, a work that was never printed. ${ }^{46}$ Between 1767 and 1773, he wrote a lengthy exhortatory treatise on Jesuit education, addressed to Jesuit teachers and students. It also remains in manuscript, and has not been studied. ${ }^{47}$

Termanini began his discussion of teachers with a strong endorsement of Jesuit humanities education, because it benefitted the students personally and helped state and society as well. Indeed, he described the benefits in more worldly and utilitarian terms than earlier Jesuits. He began with the statement that it was of the greatest importance to students and parents, as well as to the state and the Christian religion, to teach the humanities to children. Those who learn letters well will be able to support themselves and achieve worldly prosperity. Teaching the humanities well was also of great importance to the state (umana repubblica), because the majority of positions that are so important to a well-ordered state depend on a humanities education. He then invoked history: the lack of good letters caused the unhappiness of the dark ages, which lasted from 800 almost to $1400 .{ }^{48}$ Thus, Termanini endorsed the

46 See Sommervogel, Bibliothèque, 7:1931-32; and Mario Zanfredini, “Termanini, Tommaso," DHCJ 4:3779.

47 ARsI, Opp. NN. 458, entitled "Delle qualità che formano la perfezione propria di uno studente di quello istituto," discusses students, while Opp. NN. 459, entitled "Della qualità che formano la perfettione propria dei maestri delle scole inferiori di questo Istituto," addresses lower school teachers. Together they amount to about 840 pages. The work was written after 1767 because of a reference to St. José Calasanz who was canonized on July 16, 1767 (ARSI, Opp. NN. 459, f. 153), and before 1773, because of the many references to "Ours," and to individual Jesuit teachers, students, and schools in Italy, references of little relevance after 1773. The treatise has not been studied.

48 "È di sommo interesse non solo degli scolari, e dei genitori, ma ancora della Repubblica civile, e della Cristiana Religione l'istruir bene i fanciulli nelle lettere. L'interesse degli scolari, e dei loro genitori è patente, perchè la massima parte di loro dall'apprender bene le lettere aspetta, e spera il proprio mantenimento, ed avvanzamento nelle temporali prosperità. Ma quello stesso che è sommo interesse degli scolari e dei parenti loro è anche sommo interesse dell'Umana Repubblica: Imperocchè una massima parte degli impieghi, 
Renaissance humanist view of the Middle Ages as the dark ages, and the role of a humanistic education in renewing good learning.

Good instruction in speaking and writing was the foundation of all disciplines, he continued. And since instructing children in letters was of the highest importance to the state and civil life (viver civile), how much more important was it to the Catholic religion and to Christian life? He next argued that, all other things being equal, members of religious orders were better equipped to teach the humanities than secular teachers, because the former avoided the minor distractions and hair-splitting arguments in which the latter indulged. Religious order teachers showed greater zeal in teaching, which benefitted the city. Termanini then pointed out that the arrangement in which a city supported the Jesuits in exchange for teaching was a good bargain for both. Throughout Termanini offered quotations from Diodurus Siculus, Quintilian, Tertullian, St. Ambrose, and other ancient authorities in support of his statements. 49

As these examples demonstrate, Jesuit teachers believed that they were imparting a good humanistic education that would educate students to become leaders of civil and ecclesiastical society and act for the public good. Jesuit civic humanism was part of the culture of Jesuit teachers.

\section{Teacher of the Elite}

But Jesuit civic humanism had an unattractive byproduct. The Jesuits put considerable emphasis on teaching the sons of the elite, including giving them preferred treatment in class.

There are many letters by Jesuits expressing joy when the sons of nobles and other leading men of the community enrolled in their schools. This was especially the case when the Society had founded a new school that was struggling to attract students. So when the rector of the Jesuit college at Bologna wrote in 1561 that the majority of the students at the Jesuit school were sons of nobles

che la Repubblica dispensa, e che sono necessari al buon regolarmento, e felicità di essa eliggono l'esser ben fondati in lettere; e l'infelicità dei tenebrosi tempi, che corsero, cominciando dall'anno di nostra salute 800 fino quasi al 1400, per mancanza di buone lettere nel mondo, è ben nota a tutti quelli, che sono pratici della storia." Tommaso Termanini, "Lezione I: Delle industrie, che hà da uscire un maestro di scuole inferiori di questo istituto pel profitto de' suoi scolari nello studio delle lettere" (ARSI, Opp. NN. 459, ff. 1-2).

Termanini, “Lezione I," ff. 2-5. 
and other prominent figures in the town, including the son of a professor at the university, he believed that it would succeed. ${ }^{50} \mathrm{He}$ believed that other parents would follow the example of the noble parents and the professor by sending their own sons to the Jesuit school.

But Jesuits continued to write letters expressing happiness at the attendance of sons of nobles and other important people long after schools were well-established. Over time, an emphasis on social hierarchy became part of Jesuit academic culture. The Jesuit school at Bologna in the 1670 offers evidence. The majority of the students in the Jesuit school were day students who lived at home with their parents. But a substantial minority of the students came from two boarding schools that the Jesuits operated in Bologna. They were the St. Francis Xavier School for Nobles, founded in 1634, and the Blessed (later Saint) Aloysius Gonzaga School for Citizens, founded in 1645. All the students in the St. Francis Xavier school had to be of certified noble status, and all the students in the Blessed Aloysius Gonzaga had to be of citizen status, a special legal rank in some Italian cities. Citizens did not rank as high as nobles, but ranked above ordinary people. For example, citizen status usually made a man eligible for certain governmental positions denied to the population at large. Both the noble and citizen boarders lived in Jesuit-supervised residences, for which they paid high fees for food and lodging, and non-academic instruction in music, dancing, and fencing from non-Jesuit teachers. But the noble and citizen boarders attended academic classes at the regular Jesuit school, which was open to all and free of charge. In the 1670 , both the St. Francis Xavier School for Nobles and the Blessed Aloysius Gonzaga School for Citizens had about eighty boarders. They probably comprised about one-third of the students in the lower school classes of grammar, humanities, and rhetoric. ${ }^{51}$

How did the Jesuit teachers treat this mix of students who were sons of nobles, citizens, and commoners? Pietro Antonio Adami, who was neither a noble nor a citizen, tells us that the Jesuits favored the noble and citizen students.

The boarders wore distinctive uniforms: sober black, but with buttons and insignia that identified them. Ordinary students did not. Priests accompanied

50 Letter of Francesco Palmio, Bologna, May 16, 1561, in Litterae quadrimestres ex universis praeter Indiam et Brasiliam locis in quibus aliqui de Societate Jesu versabantur Romam missae ex autographis aut antiquissimis apographis depromptae, vol. 7 (Rome: Borgo S. Spirito 5, 1932), 328 .

51 Fabrini, Un documento bolognese, 23-25; and Gian Paolo Brizzi, La formazione della classe dirigente nel Sei-Settecento. I seminaria nobilium nell'Italia centro-settentrionale (Bologna: Il Mulino, 1976), 85-86 and 107-9. 
the boarders to and from their residences to the schools in the morning and at lunch, even though their residences were only steps away. They arrived just before the bell sounded. When they arrived, the other students were obliged to rise and take off their caps. If a noble student had to leave the classroom, a student "of the lower ranks" (de' più inferiori) had to accompany him. Noble and citizen students did not serve in the teacher-assistant positions of decurion, gatekeeper, or collector of student exercises. ${ }^{52}$

Teachers and other students addressed all students by their surnames in class. However, they added the title, if a noble student had one. Hence, teachers and students spoke to "Signore Conte Pepoli" or "Conte Pepoli," rather than "Signore Pepoli" or "Pepoli." Only when students became friendly with one another did they add the first name..$^{53}$ Other students were warned to limit close personal interactions with the noble and citizen students on such matters as taking or accepting money or food, or exchanging books. They risked expulsion if they violated the rules. ${ }^{54}$ At the end of the school day, priests led them back to their residences. Adami wrote that "the noble college students had precedence over all others in everything, and those from the Blessed Aloysius [School over] the other students." ${ }^{\prime 5}$

The Ratio studiorum offered a mixed message concerning the treatment of students of high social rank. It ordered Jesuit schools to treat rich and poor students the same. It forbade prefects of lower schools from excluding any student on the grounds of poverty or lack of noble birth. It told teachers that they should not look down on any student. Teachers should be as attentive to the progress of poor students as well as to the wealthy. ${ }^{56}$ On the other hand, it undercut this message of social and equality by instructing the prefect of the lower school as follows: "Of course, he should assign the better seats to those of noble families." 57

Given the hierarchical nature of society in the late sixteenth, seventeenth, and eighteenth centuries and the Jesuit conviction that the way to improve society as a whole was to educate the ruling class in civic, moral, and religious virtue, it was understandable that Jesuit schools would give preferential

$5^{2} \quad$ Fabrini, Un documento bolognese, 25.

53 "In ischuola mai si chiama alcuno per nome, che il più delle volte non si sa, ma solo per il Cognome v. g. Signor Conte Pepoli se è fra Scholari; Conte Pepoli se dal maestro si chiama; che essendovi fratelli, si distingue con aggiungere il nome." Ibid., 32.

54 Ibid., 25.

55 'Havendo i Collegiali de' Nobili la precedenza di tutti in ogni cosa, e quei del B. Luigi dagli altri scolari." (Ibid.) See also Brizzi, "La scolarité de Adami," 69.

56 Ratio studiorum, 55, 117, 155 (paragraphs 148, 259, 374).

57 Ibid., 123 (paragraph 279). 
treatment to nobles, citizens, and sons of important families. These were the future rulers of society, whose good policies based on the virtues that they learned in Jesuit schools would benefit all of society. Over time, noble schools became increasingly important in Jesuit education. In Italy alone before 1773, there were at least fifteen Jesuit noble boarding schools, and at least four Jesuit boarding schools for citizens. ${ }^{58}$ An emphasis on educating the elite was part of Jesuit pedagogical culture.

\section{The Jesuit Teacher Cares for Poor and Weak Students}

At least one Jesuit teacher criticized Jesuits who favored nobly-born and wealthy students. Tommaso Termanini devoted a passionate and stronglyworded chapter of his treatise to the topic. We have seen Jesuit teachers who have favorites among their students, he began. It is odious when a teacher favors a student because of his natural gifts, his illustrious birth, the recommendations of powerful people, or his usefulness to the teacher. ${ }^{59}$ Instead, he urged Jesuit teachers to be partial to students who need more help from the teacher, as a work of Christian charity.

Termanini acknowledged that man's corrupt nature and lower appetites inclined a teacher to pay more attention to students with rich and noble parents, and to students who were more useful to him. He admitted that it was more difficult for a teacher to exert full effort to teach students with less intellectual capacity or who resisted learning. It took hard work and sweat to reach

$5^{8}$ I have found Jesuit boarding schools for nobles in Bologna, Ferrara, Genoa, Milan, Modena, Naples, Palermo, Parma (the most famous), Prato, Ravenna, Siena, and Turin, plus noble schools at Brescia, Padua, and Verona that had to close in 1591 (Padua) and 1606 (Brescia and Verona) when the Jesuits were expelled from the Republic of Venice. There were citizen boarding schools in Bologna, Genoa, Monza, and Savona. Not all of these schools lasted very many years. Brizzi, La formazione, is an excellent study that concentrates on the noble schools at Bologna, Modena, Parma, and Siena, and there are good studies of the Parma school. But more research is needed.

59 "L'usare parzialità coi proprij scolari abbiam veduto, che rende odiosà in un col maestro fautore gli scolari favoriti. Ma questo s'intende quando il favore parziale del maestro proviene da qualche passione, non quando deriva da virtù e carità cristiana. Questo s'intende quando il maestro è ad assistere particolarmente lo scolare favorito o dalle doti naturali e personali dello scolare che l'allettano, o dalla nascita più illustre, o dalle raccomandazioni di persone poteriti, o dall'utile che il maestro ricavi." ARSI, Opp. NN. 459, ff. $150-51$. 
them. ${ }^{60}$ It was easy to abandon them, because the teacher realized that the results would be somewhat disappointing. Termanini pictured two kinds of students: those who were rough, clumsy, reluctant to learn, recalcitrant, and ungrateful, and students who were sweet-tempered, docile, loving, and manageable. The former were difficult to teach, the latter easy. Nevertheless, he urged teachers to strive to teach the former. ${ }^{61}$

Termanini then stated that religious order teachers who sought to reach salvation in the next life through the ministry of teaching had a particular calling to help poor and less capable students. He quoted St.José Calasanz (1557-1648), at times a critic of the Jesuits, on this point. ${ }^{62}$ Calasanz created a school for poor boys in Rome in 1597 and founded the Piarists (Poor Clerks Regular of the Mother of God of the Pious Schools), recognized by the papacy in 1617, to continue his work. The Scuole Pie (Pious Schools) offered free vernacular education to poor boys. Although the Piarists later added Latin instruction and schools for nobles, they remained reasonably faithful to their original ministry. ${ }^{63}$ Termanini did not have to remind Jesuit readers that the Piarist schools competed with the Society for students.

Termanini next pointed out that it was difficult for a teacher to obtain good educational results from poor students if they lacked books, paper, and other pedagogical supplies. This was a reminder that students in Jesuit schools required books plus a lot of paper and ink to write, correct, and rewrite the daily composition exercises. The teacher who wanted poor children to succeed must either persuade others to provide the needed materials or give them from his own supplies. ${ }^{64}$ It is likely that many Jesuit teachers did supply materials to students who needed them.

Termanini then offered his interpretation of the New Testament passages in which Jesus urged children to come to him for his blessing (Matthew 19:13-15; Mark 10:13-16; Luke 18:15-17). Christ did not call the son of a rich or powerful

6o "Certamente la corrotta e guasta natura e gli inferiori appetiti non inclinano il maestro spendere le sue fatiche e i suoi sudori aprò di certe indoli sgraziate, rozzi, riluttanti, ingrati." Ibid., ff. $152-53$.

61 Ibid., ff. 150-53.

62 Ibid., ff. 153-54.

63 For a brief introduction to the Piarists with much bibliography, see Grendler, Schooling in Renaissance Italy, 381-90; and Grendler, "The Piarists of the Pious Schools," in Religious Orders of the Catholic Reformation. In Honor of John C. Olin on his Seventy-fifth Birthday, ed. Richard L. DeMolen (New York: Fordham University Press, 1994), 252-78, reprinted in Grendler, Renaissance Education Between Religion and Politics (Aldershot: Ashgate, 2006), $252-78$.

64 ARSI, Opp. NN. 459, f. 154. 
man to come to him, but a poor child who ran in the streets, Termanini commented. He did not call a well-taught child of capable intellect, but one who was rough and ignorant. He did not call children who were disciplined and well-educated, but uncouth and unlearned children. They needed special help, not the rich student. Termanini concluded with his overall message: the schoolmaster truly imitated his divine teacher if he showed partiality toward poor students, and if he gave special help to the most needy students. ${ }^{65}$

Termanini was a Jesuit teacher speaking to his fellow teachers. According to him, some Jesuit teachers favored students who had rich and powerful parents, and/or were useful, intellectually very capable, and docile. Termanini did not recommend any organizational or policy changes for Jesuit schools. Instead, he exhorted his fellow teachers to help poor, less capable, and more difficult students. It is likely that many Jesuit teachers did.

\section{Conclusion}

The culture of the Jesuit teacher had several elements. First, he was a teacher. Teaching was the primary part of the identity of every Jesuit (except for the brothers). Second, he was the leader and manager of a large classroom of boys and youths. This must have required a good deal of skill, determination, and self-confidence. Third, he was an integral part of a highly competitive academic culture. He fostered competition in his students, and he tried to be the best teacher that he could be. Fourth, he believed that he would make civil and ecclesiastical society better by educating its future leaders in eloquence, wisdom, and virtue. Fifth, Jesuit pedagogical culture included a strong sense of social hierarchy. It gave preference to well-born students in the classroom. Sixth, the culture of the Jesuit teacher did not let him forget the lowborn and academically weak students in his classroom. Some Jesuit teachers felt compassion for these students and urged that they receive as much attention as possible.

65 Ibid., ff. $155^{-5} 8$. 